Sournals
INTERNATIONAL JOURNAL OF
ORGANIZATIONAL LEADERSHIP $\begin{gathered}\text { INDUSTRIAL } \\ \text { MANAGEMENT } \\ \text { INSTITUTE }\end{gathered}$

\title{
An investigation of the impact of the knowledge sharing and the characteristics of learning organization on employees' organizational intelligence
}

\author{
Mojtaba Babapour ${ }^{1,2^{*}}$, Bahram Gheibi ${ }^{2}$ \\ ${ }^{1}$ Department of Management, Ardabil Science and Research Branch, Islamic Azad University, Ardabil, Iran \\ ${ }^{2}$ Department of Management, Ardabil Branch, Islamic Azad University, Ardabil, Iran
}

\begin{abstract}
Keywords:

Knowledge Sharing, Characteristics of Learning Organization, Organizational Intelligence, Red Crescent Society

Received

26 November 2015

Received in revised form 3 May 2016

Accepted

13 May 2016

Correspondence:

m.babapour2013@gmail.com

The aim of this study was to investigate the impact of the knowledge sharing and the characteristics of learning organization on employees' organizational intelligence in Red Crescent Society of Ardabil Province. The present study was a descriptive correlational research in terms of method and a survey research in terms of data collection. The population for the study consisted of the entire staff of Crescent Society of Ardabil Province which was equal to 210 individuals. Due to the limited statistical population, instead of sampling, all 210 employees were selected as the sample. Among 210 questionnaires, a total of 190 questionnaires were returned and entered the analysis. In this research, the data gathering tools were the learning organization questionnaire by Mahmoodzadeh (2005), Albrecht's (2003) organizational intelligence questionnaire, and Pai's knowledge sharing questionnaire (2006). In order to analyze the collected data, SPSS software was conducted and to analyze the hypotheses, simple and multiple regressions were used. Results indicated that the knowledge sharing and its components had a positive and significant impact on organizational intelligence of the employees of Red Crescent Society of Ardabil province. Moreover, the characteristics of learning organization and its components had a positive and significant impact on organizational intelligence of the employees of Red Crescent Society of Ardabil Province.
\end{abstract}

(C)AIMI Journals

\section{Introduction}

With the growth of knowledge-based thought as a strategic resource in the 21st century, knowledge attracted attention as an important competitive advantage in the pioneer 
organizations. Therefore, in recent times, many scientists of management and organization science have initiated some activities to systematize knowledge usage in government organizations through developing a new field in management under the title of "knowledge management in government organizations”. Gaining competitive advantage is one of the characteristics of knowledge and it must be noticed that knowledge management is of greater value than knowledge (King, 2005).

One of the strategic steps in knowledge management is knowledge sharing. In fact, the organizations must manage and bring the appropriate type of knowledge related to their processes under control. Moreover, they must consider knowledge as an important resource for developing and keeping competitive advantage in the organization and especially pay attention to knowledge sharing to improve the performance of government organization's processes in the competitive environment (Han, \& Anantatmula, 2007).

Knowledge sharing is defined as the culture of knowledge-based interactions which includes the exchange of tacit and explicit knowledge, experience, and skills of employees in the organizational units or in the whole organization (Pai, 2006).

If the personalized knowledge is not shared, the employees will enter the learning process separately and will show no tendency to share their knowledge with other members (MacNeil, 2003). In fact, knowledge sharing can simultaneously influence personal abilities and organizational competence and improve the ability of organization's intellectual capitals in the field of human and organization capitals (Magnier-Watanabe \& Senoo, 2008).

The variables of learning organization and organizational intelligence are investigated separately and through other variables. However, knowledge sharing and organizational learning in the learning organization and the impact of these two variables on organizational intelligence must be studied.

The main question of the present study is that what impacts do knowledge sharing and the characteristics of learning organization have on organizational intelligence of employees of Red Crescent Society of Ardabil Province?

\section{The Literature Review}

The organization's approach as a learning system was first proposed in early 20th century. When the management realities are stated and measured for a manager, they can easily transfer their learning to the other individuals and hence increase the efficiency of the organization. In 1950, the approach of learning organizations was amended and reviewed by theorists like Richard Cyert, James March, and Herbert Simon. According to most researches, the concept of learning organization has attracted countless attention of researches and leaders of the organizations. From 1980s, experts such as Pedler, Argyris, Schon, Marsick, Watkins, and Gephardt entered the field of learning organization and each one adopted a particular approach and defined this concept. However, everyone acknowledges that the book by Peter Senge under the title of "The fifth discipline: The art and practice of learning organization" is the most important intellectual process of this paradigm and Senge is the founder of scientific thinking of learning organization in previous years.

Senge (1990) presented a conceptual definition of learning organization as an environment where people continually expand their capacity to create the results they truly desire, where 
new and expansive patterns of thinking are nurtured, where collective aspiration is set free, and where people are continually learning to see the whole together. According to Senge, the five components of learning organization are personal mastery, mental models, shared vision, team learning, and systems thinking are the intended components of learning organization in this research.

Albercht (2003), the writer and designer of organizational intelligence, defines organizational intelligence as the organization's capacity of mental faculty to carry responsibility which includes seven components, namely strategic vision, shared fate, appetite for change, heart, alignment congruence, knowledge deployment, and performance pressure which are the intended components of organizational intelligence in this research.

Since today's organizations are facing challenges, paying attention to the organizational intelligence process in order to further improve the performance and growth through investigating and promoting strategic vision, shared fate, appetite for change, heart, alignment congruence, knowledge deployment and performance pressure which are the dimensions of organizational intelligence is vital. Simic (2005) defined organizational intelligence as the thoughtful ability of an organization for solving its problems. His emphasis is on the combination of human and his technical ability for solving organizational matters. Halal (1998) believes that organizational intelligence is the capacity of an organization in creating knowledge and strategically utilizing it to adapt it to the surrounding environment. According to Yolles (2005), the concept of organizational intelligence includes detailed paradigms like organizational learning and knowledge management.

\section{Method}

The present study was a descriptive correlational research in terms of method and a survey research in terms of data collection. The aim of the current study was to investigate the impact of the knowledge sharing and the characteristics of learning organization on employees' organizational intelligence. The population for the study consisted of the entire staff of Crescent Society of Ardabil Province which was equal to 210 individuals. Following this, due to the limited statistical population the whole statistical population were selected as the sample of the study. Among 210 questionnaires, 190 questionnaires were returned and entered the analysis.

In this research, the data was gathered first through library method and using special cards and then through field method and using questionnaire. The tools for data collection involved three questionnaires: The learning organization questionnaire by Mahmoodzadeh (2005) which includes 25 questions and five-point Likert scale and measures the five dimensions of learning organization; the organizational intelligence questionnaire by Albrecht (2003) which includes 49 questions and five-point Likert scale and measures the seven dimensions of organizational intelligence; and the knowledge sharing questionnaire by Pai (2006) which includes 15 questions and five-point Likert scale and measures the dimensions of knowledge sharing.

\section{The Validity and Reliability of the Questionnaire}

In order to measure the validity of the questionnaires, content validity was adopted. In other words, the questionnaires were distributed among the professors and their opinions about the 
quality of the questionnaires as a valuable tool for measuring the variables were asked. Finally, they confirmed the questionnaires. To measure the reliability of the questionnaires, Cronbach's Alpha was used. Knowledge sharing contained 15 questions, the characteristics of learning organization had 25 questions, and organizational intelligence involved 49 questions and their Cronbach's alphas were $0.79,0.81$, and 0.86 , respectively.

\section{Results}

In order to analyze the data, SPSS software was used. At first, descriptive statistics which include frequency tables and different diagrams to investigate demographic variables (statistical samples and target population) were used. Then, simple and multiple regressions were conducted to analyze the hypotheses. In the current study, 89.47 per cent of participants were men and 10.53 per cent were women. In addition, 10 per cent of participants were under 30 years old, 29.47 per cent, 44.74 per cent, and 15.78 percent were between 30 to 40 years old, 41 to 50 years old, and over 50 years old, respectively. Considering the education, 30 per cent were diploma or under diploma, 14.74 per cent had associate degree, and 50.52 per cent, 3.69 per cent, and 1.05 per cent had $\mathrm{BA}, \mathrm{MA}$, and $\mathrm{PhD}$ degrees, respectively.

Table 1 shows the summary of the regression model of the knowledge sharing impact on organizational intelligence.

Table 1

The Summary of the Regression Model of the Knowledge Sharing Impact on Organizational Intelligence

\begin{tabular}{cccc}
\hline Correlation Coefficient & Coefficient of Determination & Adjusted Coefficient of Determination & Durbin-Watson \\
\hline 0.665 & 0.442 & 0.427 & 1.718 \\
\hline
\end{tabular}

According to Table 1, the correlation coefficient of the knowledge sharing and its dimensions with organizational intelligence is equal to 0.66 and the coefficient of determination is 0.44. If Durbin-Watson statistic is between 1.5 and 2.5, there will be no correlation between errors. Since Durbin-Watson statistic is equal to 1.71 , it can be concluded that there is no correlation between errors.

Table 2

The Results of Multiple Regression of the Knowledge Sharing Impact on Organizational Intelligence

\begin{tabular}{|c|c|c|c|c|c|}
\hline \multirow[t]{2}{*}{ Predictor Variable } & \multicolumn{2}{|c|}{ Non-Standard Coefficients } & \multirow{2}{*}{$\frac{\text { Standard Coefficient }}{\text { BETA }}$} & \multirow[t]{2}{*}{$\mathrm{t}$} & \multirow[t]{2}{*}{$\mathrm{P}$} \\
\hline & B & SE & & & \\
\hline Fixed Value & 69.934 & 6.996 & & 9.996 & 0.000 \\
\hline Sequential Knowledge Sharing & 2.511 & 1.097 & 0.265 & 2.289 & 0.023 \\
\hline Explicit Knowledge Sharing & 3.345 & 1.529 & 0.313 & 2.187 & 0.030 \\
\hline Tacit Knowledge Sharing & 4.372 & 1.865 & 0.394 & 2.345 & 0.020 \\
\hline Strategic Knowledge Sharing & 7.682 & 1.513 & 0.641 & 5.076 & 0.000 \\
\hline Knowledge Sharing & 2.878 & 0.998 & 0.704 & 6.881 & 0.002 \\
\hline
\end{tabular}

Table 2 represents the results of multiple regression of the knowledge sharing impact on organizational intelligence. According to Table 2, since the significance level is less than 0.01, thus the knowledge sharing has a positive and significant impact on employees’ organizational 
intelligence. Moreover, BETA indicates that sequential knowledge sharing (0.26), explicit knowledge sharing (0.31), tacit knowledge sharing (0.39), strategic knowledge sharing (0.64), and knowledge sharing (0.70) predict the changes of organizational intelligence.

Table 3

The Regression Model Summary of the Characteristics of Learning Organization Impact on Organizational Intelligence

\begin{tabular}{cccc}
\hline Correlation Coefficient & Coefficient of Determination & Adjusted Coefficient of Determination & Durbin-Watson \\
\hline 0.716 & 0.513 & 0.500 & 1.791 \\
\hline
\end{tabular}

Table 3 exhibits the regression model summary of the characteristics of learning organization impact on organizational intelligence. According to Table 3, the correlation coefficient of the characteristics of learning organization with organizational intelligence is equal to 0.71 and the coefficient of determination is 0.51. If Durbin-Watson statistic is between 1.5 and 2.5, there will be no correlation between errors. Since Durbin-Watson statistic is equal to 1.79 , it can be concluded that there is no correlation between errors. Table 4 presents the results of the multiple regression of the characteristics of learning organization impact on organizational intelligence.

Table 4

The Results of the Multiple Regression of the Characteristics of Learning Organization Impact on Organizational Intelligence

\begin{tabular}{lcccccc}
\hline Predictor variable & \multicolumn{2}{c}{ Non-standard Coefficients } & Standard coefficient & $\mathrm{t}$ & $\mathrm{P}$ \\
\cline { 2 - 3 } & $\mathrm{B}$ & $\mathrm{SE}$ & $\mathrm{BETA}$ & & & \\
\hline Fixed Value & 53.011 & 7.356 & & 7.207 & 0.000 \\
Mental Model & 1.552 & 0.700 & 0.263 & 2.218 & 0.028 \\
Shared Vision & 3.417 & 0.992 & 0.350 & 3.446 & 0.001 \\
Learning Ability & 3.118 & 0.912 & 0.287 & 2.850 & 0.001 \\
Team Learning & 1.615 & 0.921 & 0.282 & 2.668 & 0.015 \\
Systems Thinking & 2.350 & 0.802 & 0.340 & 2.636 & 0.007 \\
The Characteristics of Learning Organization & 0.959 & 0.377 & 0.520 & 2.543 & 0.012 \\
\hline
\end{tabular}

According to Table 4, since the significance level is less than 0.01 , it can be concluded that the characteristics of learning organization have a positive and significant impact on employees’ organizational intelligence. Moreover, BETA indicates that mental model (0.26), shared vision (0.35), learning ability (0.28), team learning (0.28), systems thinking (0.34), and the characteristics of learning organization (0.52) predict the changes of organizational intelligence.

\section{Discussion and Conclusion}

The results of the present study indicated that the knowledge sharing and its components have a positive and significant impact on organizational intelligence of employees of Red Crescent Society of Ardabil Province. Moreover, the characteristics of learning organization and their 
components have a positive and significant impact on organizational intelligence of employees of Red Crescent Society of Ardabil Province.

The findings of this research are in line with the findings of research conducted by Sattari Ghahfarokhi (2007). In this study, the relationship between the sub-system of knowledge management in learning organization and the components of organizational intelligence has been investigated. The results showed that according to the Pearson Correlation Coefficient, there is a positive and significant relationship between the sub-system of knowledge management and organizational intelligence and a positive and significant relationship between the sub-system of knowledge management and all the components of organizational intelligence. Finally, the results of stepwise regression for shared fate in the level of 73.5 indicated that among the components of organizational intelligence, shared fate, knowledge deployment, and alignment congruence could significantly predict the sub-systems of knowledge management in learning organization. In the present study, the impact of the characteristics of learning organization components on organizational intelligence has been investigated.

The results of this research are also in line with the findings of the research done by Molaeian and Eslamieh (2010). They investigated the relationship between Saipa Company's dimensions of the learning organization and organizational intelligence. According to the results, there is a positive and significant relationship between the components of learning organizations and the components of organizational intelligence of Saipa Company's managers. The results of regression indicated that among the components of learning organization, systems thinking skills, shared vision, personal skills, team learning, and mental model could respectively predict the organizational intelligence of Saipa Company's managers.

Banisi and Malekshahi (2010) conducted a research under the title of "A study of the relationship between the components of organizational intelligence and learning organization in Islamic Azad University”. The results indicated that there is a significant relationship between the components of organizational intelligence (strategic vision, shared fate, appetite for change, heart, alignment congruence, knowledge deployment, and performance pressure) and learning organization.

In the research conducted by Shariati and Fatehipour (2010) under the title of "Studying the impact of knowledge management on organizational intelligence (case study: Islamic Azad University, Sanandaj Branch)", the results showed that there is a relationship between knowledge management and organizational intelligence. According to the findings, in the present era, dealing with organizational intelligence by means of the existing knowledge is a necessity and utilizing it is one of the most important competitive advantages of business.

Azizi (2007) have reported positive and significant findings about the relationship between the components of organizational intelligence and the development of organizational knowledge management.

In the research conducted by Taheri Lari (2010) under the title of "The place of knowledge management in organizational intelligence” in Islamic Azad University, Mashhad Branch, the process of analysis was inductive and through using the findings of reviewing theoretical foundations in the field of knowledge management and organizational intelligence. The results 
demonstrated that there is a close relationship between knowledge management and organizational intelligence.

In another research by Albrecht (2003) on the relationship between organizational intelligence and knowledge management, he presented a model for organizational intelligence and knowledge management. By combining swarm intelligence of Albrecht and smart and thoughtful managers and leaders, the executive directors can activate the individuals' mental power. This fact is the result of a challenge between organizational intelligence and knowledge management.

Liao, Fei, and Liu (2008) in a research under the title of "Relationships between knowledge inertia, organizational learning and organization innovation” expressed that first, knowledge inertia impacts on organization innovation with the mediation of organizational learning. Second, when the members of the organization have less knowledge inertia or experience less inertia, the performance of organizational learning will improve.

According to the results of this study, knowledge sharing has a positive and significant impact on organizational intelligence of employees of Red Crescent Society of Ardabil Province. Therefore, to promote organizational intelligence, it is recommended that the experts of Red Crescent Society of Ardabil Province should step by step write and explain the new knowledge which is used in the organization. Moreover, the newcomers should have an instructor who can show them the right way in the organization. Knowledge should also be distributed informally in Red Crescent Society of Ardabil Province. In addition, there should be regular meetings in the organization on specialized topics and colleagues should repeatedly inform one another about positive experience and successful projects.

According to the results of the study, the characteristics of learning organization have a positive and significant impact on organizational intelligence of employees of Red Crescent Society of Ardabil Province. Therefore, to develop organizational intelligence, it is recommended that the employees of Red Crescent Society of Ardabil Province redouble their efforts and the strategies of Red Crescent Society of Ardabil Province be evaluated annually. Moreover, the statement of purpose for Red Crescent Society of Ardabil Province should clearly be represented and its managers' attitudes should be towards working. Moreover, all the employees should participate in the programs and achievements of the organization and the structure of Red Crescent Society of Ardabil Province should be proportional to working process. In addition, operational policies should support the mission of Red Crescent Society of Ardabil Province and finally, the professional learning and growth of employees should be encouraged.

\section{References}

Albrecht, K. (2003). Organizational intelligence survey preliminary assessment Australian managers. Australian Institute of Management. Retrieved from http://www.aim.com.au.

Azizi, A. (2007). Organizational intelligence and its relationship with the development of organizational knowledge management in Fars Province Organization of Agriculture Jahad (Unpublished master's thesis). Payame Noor University, Shiraz, Fars.

Banisi, P., \& Malekshahi, A. (2010). A study of the relationship between the components of organizational intelligence and learning organization in Islamic Azad University, Roudehen Branch. Educational Sciences, 3(11), 131-142.

Halal, W. E. (1998). Organizational intelligence: What is it, and how can managers use it? Knowledge Management Review, 1, 20-25. 
Han, B. M., \& Anantatmula, V. S. (2007). Knowledge sharing in large IT organizations: A case study. VINE: The Journal of Information and Knowledge Management Systems, 37(4), 421-439.

King, W. R. (2005). Communications and information processing as a critical success factor in the effective knowledge organization. International Journal of Business Information Systems, 1(1/2), 31-52.

Liao, S., Fei, W. C., \& Liu, C. T. (2008). Relationships between knowledge inertia, organizational learning and organization innovation. Technovation, 28(4), 183-195.

MacNeil, C. M. (2003). Line managers: Facilitators of knowledge sharing in teams. Employee Relations, 25(3), $294-307$.

Magnier-Watanabe, R., \& Senoo, D. (2008). Organizational characteristics as prescriptive factors of knowledge management initiatives. Journal of Knowledge Management, 12(1), 21-36.

Mahmoodzadeh, S. (2005). Surveying the readiness of ministries of education in the provinces of Iran to transform into a learning organization (Unpublished master's thesis). Tarbiat Modares University, Tehran, Iran.

Molaeian, S., \& Eslamieh, F. (2010). Investigation into the relationship between Saipa Company’s dimensions of the learning organization and organizational intelligence. Journal of Modern Industrial/Organizational Psychology, 1(4), 77-88.

Pai, J. C. (2006). An empirical study of the relationship between knowledge sharing and IS/IT strategic planning (ISSP). Management Decision, 44(1), 105-122.

Sattari Ghahfarokhi, M. (2007). Surveying the relationship between organizational intelligence and organizational culture (Unpublished master’s thesis). Islamic Azad University of Isfahan, Isfahan, Iran.

Senge, P. (1990). The fifth discipline: The art and practice of the learning organization. New York: Doubleday.

Shariati, H., \& Fatehipour, M. (2010). Studying the impact of knowledge management on organizational intelligence (case study: Islamic Azad University, Sanandaj Branch). Paper presented at the First National Conference on Organizational/Business Intelligence, Tehran, Iran.

Simic, I. (2005). Organizational learning as a component of organizational intelligence. Journal of Information and Marketing Aspect of the Economically Development of the Balkan the Balkan Countries, 32(3), 189-196.

Taheri Lari, M. (2010). The place of knowledge management in organizational intelligence. Paper presented at the First National Conference on Organizational/Business Intelligence, Tehran, Iran.

Yolles, M. (2005). Organizational intelligence. The Journal of Workplace Learning, 17(1/2), 99-114. 